\section{Root Weight, Nonstructural Carbohydrate Content, and Shoot Density of High-density Creeping Bentgrass Cultivars}

\author{
Patricia Sweeney, Karl Danneberger ${ }^{1}$, and Daijun Wang \\ Department of Horticulture and Crop Science, Ohio State University, Columbus, \\ $\mathrm{OH} 43210$
}

\section{Michael McBride \\ Muirfield Village Golf Club, Dublin, OH 43017}

Additional index words. Agrostis stolonifera, carbohydrate reserves, tillers, turfgrass

\begin{abstract}
Limited information is available on the performance under temperate conditions in the United States of recently released cultivars of creeping bentgrass (Agrostis stolonifera $\mathbf{L}$.) with high shoot density for use on golf course putting greens. Fifteen cultivars were established in Aug. 1996 on a greens mix with high sand content to compare their seasonal weights and total nonstructural carbohydrate (TNC) contents. The cultivars were maintained at $3.1 \mathrm{~mm}$ height of cut. Shoot density counts were taken during Apr., July, and Oct. 1998. Root weights and nonstructural carbohydrate levels were assessed monthly from June 1997 through Nov. 1998. A cultivar group contrast between the high shoot density cultivars ('Penn A1', 'Penn A2', 'Penn A4', 'Penn G1', 'Penn G2', and 'Penn G6') and the standard cultivars ('Penncross', 'Crenshaw', 'Southshore', 'DF-1', 'Procup', 'Lopez', 'SR1020', and 'Providence') revealed that the former averaged 342.9 and 216.1 more shoots $/ \mathrm{dm}^{2}$ on two of the three sampling dates. Root dry weights did not vary significantly $(P \leq 0.05)$ among the cultivars. Performing a contrast between new high shoot density cultivars and standard cultivars revealed greater root dry weight in the former during Mar. and May 1998. Differences $(P \leq 0.05)$ in TNC were observed on two of the 18 sampling dates, but no trends were evident.
\end{abstract}

Recently, new creeping bentgrass cultivars with high shoot density have been released (Croce et al., 1998) and commercialized for use on golf course putting greens. These cultivars are presumably tolerant to low mowing heights and resistant to both abiotic and biotic stresses. Many golf courses in temperate regions have converted or are considering conversion to these new cultivars with increased tolerance to disease and heat stress, as well as finer texture, increased density, and optimum ball roll.

Information on the behavior of these cultivars in temperate regions is limited. Croce et al. (1998) compared the characteristics of high shoot density vs. standard cultivars in a

Received for publication 23 Nov. 1999. Accepted for publication 17 July 2000. Salaries and research supported by State and Federal Funds appropriated to the Ohio Agriculture Research and Development Center, The Ohio State Univ. Additional support provided by the Ohio Turfgrass Foundation. Mention of a trademark, propriety product, or vendor does not constitute a guarantee or warranty of the product by the Ohio State Univ. and does not imply its approval to the exclusion of other product or vendors that may also be suitable. The cost of publishing this paper was defrayed in part by the payment of page charges. Under postal regulations, this paper therefore must be hereby marked advertisement solely to indicate this fact.

${ }^{1}$ To whom reprint requests should be addressed. Email address: danneberger.1@osu.edu
Mediterranean climate. In general, they concluded that the former had higher quality and experienced less invasion by Poa annua L. and moss.

Given the low mowing height to which the new cultivars are subjected $(<3.1 \mathrm{~mm})$, their ability to withstand heat stress is of particular interest. Root weight and total nonstructural carbohydrate (TNC) are often used as indirect indicators of the tolerance of turfgrass to stress. Under summer stress, root weight of stress-tolerant Kentucky bluegrass (Poa pratensis L.) genotypes was greater than that of intolerant genotypes (Bonos and Murphey, 1999). Huang et al. (1998) concluded that high temperature reduced root growth of creeping bentgrass cultivars and that this could contribute to cultivar variations in quality. Nonstructural carbohydrate is considered the energy currency to be spent during stress (Hull, 1992) and has been used as a physiological measure of stress tolerance (Beard, 1973; Sheffer et al., 1979, Watschke et al., 1972, 1973). Watschke et al. (1970) found that Kentucky bluegrass genotypes that tolerated heat stress produced more roots and maintained higher carbohydrate reserves at high temperatures.

Although any differences in root weight and TNC concentration are of interest, the timing of measurements is critical to interpreting the results. Differences in root weight and TNC concentration when the plants are under stress, are important in determining whether the newer cultivars can tolerate stress conditions. Ideally, these cultivars have increased root weight and TNC reserves to support their increased shoot numbers. Since field stress cannot be accurately predicted in advance, we chose to follow seasonal variation in root weight and TNC concentration over the course of two growing seasons.

The objectives of our research were: 1) to determine if there were seasonal differences in rooting patterns and TNC concentration between six high shoot density and eight standard creeping bentgrass cultivars on putting greens in the temperate region; and 2) to verify the increased shoot density of the new cultivars.

\section{Materials and Methods}

Fourteen creeping bentgrass cultivars and one creeping bentgrass blend were seeded 16 Aug. 1996 at $73 \mathrm{~kg} \cdot \mathrm{ha}^{-1}$ on a nursery green with a high sand content $[80$ sand : 20 peat (v/v)] at Murifield Village Golf Course, Dublin, Ohio. The 2.2- $\mathrm{m}^{2}$ plots were arranged in a randomized complete-block design with each cultivar replicated three times. High shoot density cultivars in the studies included 'Penn A1', 'Penn A2', 'Penn A4', 'Penn G1', 'Penn G2', and 'Penn G6'. 'Penncross', 'Crenshaw', 'Southshore', 'DF-1', 'Procup', 'Lopez', 'SR1020', and 'Providence' were included as standard cultivars, as well as 1 'Penncross': 1 'Crenshaw' (w/w). During establishment, the plots were mowed at 11 $\mathrm{mm}$. The height of cut was gradually lowered to $3.1 \mathrm{~mm}$ (Mar. to July 1997) where it remained through the duration of the study. From 16 Aug. 1996 to 30 June 1997 the cultivars received $400 \mathrm{~N}-81.4 \mathrm{P}-71.2 \mathrm{~K} \mathrm{~kg} \cdot \mathrm{ha}^{-1}$, respectively. Nitrogen was applied at a rate of $25-37 \mathrm{~kg} \cdot \mathrm{ha}^{-1}$ per month during the growing season from 1 July 1997 to 30 Aug. 1998; sources were urea and methylene urea. Plots were topdressed with $0.15-0.3 \mathrm{~mm}$ sand once every 3 weeks during the growing season. Irrigation was provided as needed to prevent wilt. The plots received no traffic other than normal maintenance operations.

Root samples $\left(5 \mathrm{~cm}^{2} \times 10 \mathrm{~cm}\right.$ cores $)$ were collected monthly from June 1997 to Nov. 1998. Roots were hand-washed over a finemesh screen to remove soil particles, dried at $70{ }^{\circ} \mathrm{C}$, weighed, and stored at $-20{ }^{\circ} \mathrm{C}$. Percentage of TNC in root samples was determined using a modified Smith protocol (Smith, 1968, 1981). After processing in a cyclone mill (Udy Analyzer, Boulder, Colo.) through a $1.0-\mathrm{mm}$ mesh screen, $40-$ to $60-\mathrm{mg}$ samples were boiled for $5 \mathrm{~min}$ in water, then incubated with $\alpha$-amylase and amyloglucosidase for $24 \mathrm{~h}$ at $45^{\circ} \mathrm{C}$. After filtration and protein precipitation with $0.31 \mathrm{~m}$ lead acetate, fructosans were hydrolyzed in $0.01 \mathrm{~N}$ sulfuric acid. Concentration of TNC was determined by titrating with $0.02 \mathrm{~N}$ sodium thiosulfate using gelatinized starch as indicator. Percentage of TNC was calculated for each sample based on the weight of the tissue digested in the analysis. Cores $(5 \mathrm{~cm}$ diam- 
eter) for shoot density counts were collected from each plot in Apr., July, and Oct. 1998 and stored at $-20{ }^{\circ} \mathrm{C}$. Shoot density was determined by counting the number of tillers (including loose tillers) in each core (Skogley and Sawyer, 1992).

Analysis of variance was performed each month for root weight and percentage of TNC and for three sampling dates for shoot counts on all 15 entries. Contrasts (Steele and Torrie,
1980) between the six high shoot density cultivars and the eight standard cultivars were performed for the same three variables each month.

\section{Results and Discussion}

The number of tillers $/ \mathrm{dm}^{2}$ differed significantly $(P \leq 0.05)$ among the cultivars in July, but not in April or October (Table 1).
Four of the five cultivars with the highest shoot densities in July and six of the top seven in April were Penn " $A$ " and " $G$ " series bentgrasses. A contrast of high shoot density cultivars vs. standard cultivars revealed significantly $(P \leq 0.05)$ more tillers during April and July, in the former. No difference was found in the October sampling, which does not agree with the data of Croce et al. (1998) who collected their data in September.
Table 1 . Mean shoot density (tillers $/ \mathrm{dm}^{2}$ ) for 15 creeping bentgrass cultivars in 1998 .

\begin{tabular}{|c|c|c|c|}
\hline \multirow[b]{2}{*}{ Cultivar } & \multicolumn{3}{|c|}{ Month } \\
\hline & Apr. & July & Oct. \\
\hline \multicolumn{4}{|c|}{ High shoot density cultivars } \\
\hline Penn A1 & 1614 & 1496 & 1503 \\
\hline Penn A2 & 1564 & 1981 & 1658 \\
\hline Penn A4 & 1747 & 1791 & 1699 \\
\hline Penn G1 & 1600 & 1595 & 1496 \\
\hline Penn G2 & 1554 & 1669 & 1609 \\
\hline Penn G6 & 1692 & 1816 & 1747 \\
\hline \multicolumn{4}{|c|}{ Standard cultivars } \\
\hline Penncross & 1092 & 1593 & 1133 \\
\hline Crenshaw & 1418 & 1613 & 1747 \\
\hline Southshore & 1479 & 1510 & 1562 \\
\hline DF-1 & 1225 & 1507 & 1601 \\
\hline Procup & 1126 & 1365 & 1650 \\
\hline Lopez & 1203 & 1525 & 1487 \\
\hline SR 1020 & 1517 & 1531 & 1528 \\
\hline Providence & 1225 & 1424 & 1406 \\
\hline Penncross/Crenshaw & 1245 & 1658 & 1520 \\
\hline Mean & 1420 & 1605 & 1556 \\
\hline LSD & NS & $297^{*}$ & NS \\
\hline \multicolumn{4}{|c|}{ Mean } \\
\hline High shoot density cvs. & 1629 & 1725 & 1619 \\
\hline Standard cvs. & 1286 & 1509 & 1514 \\
\hline Significance & $*$ & * & NS \\
\hline
\end{tabular}

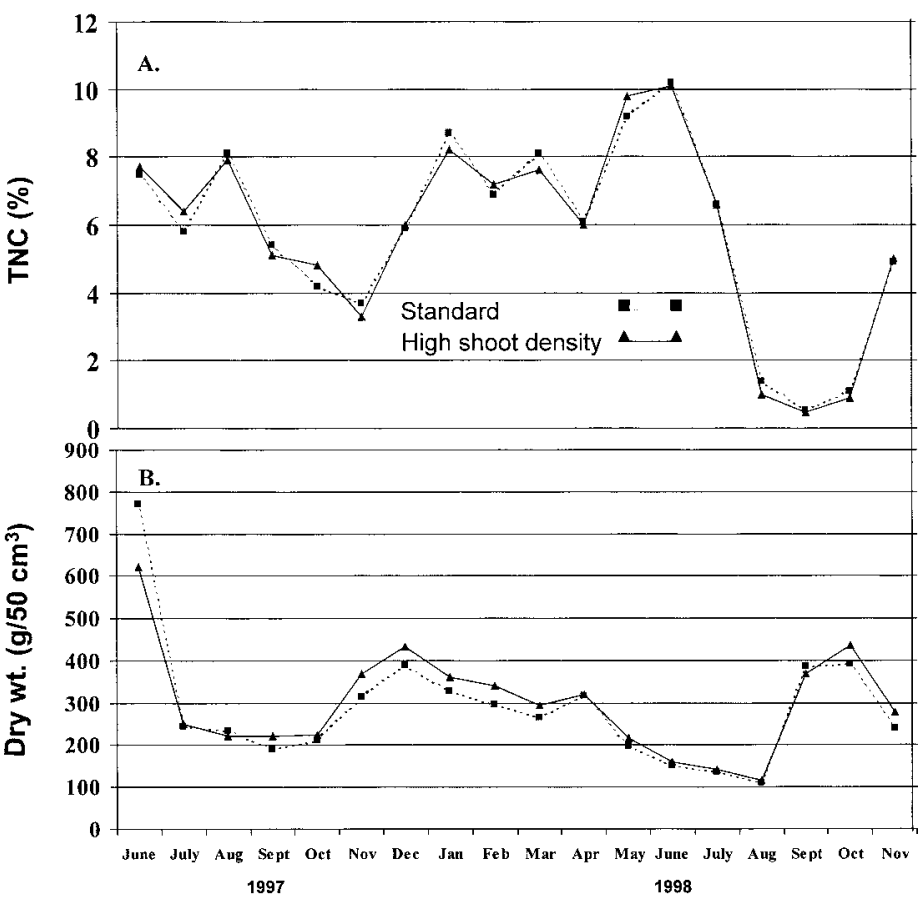

Fig. 1. Comparison of (A) total nonstructural carbohydrate content and (B) seasonal root weight of high shoot density vs. standard creeping bentgrass cultivars. "Significant $(P \leq 0.05)$ contrast between high shoot density and standard cultivars.

Table 2. Monthly means of percentage of total nonstructural carbohydrate content of 15 creeping bentgrass cultivars from June 1997 to Nov. 1998.

\begin{tabular}{|c|c|c|c|c|c|c|c|c|c|c|c|c|c|c|c|c|c|c|}
\hline \multirow[b]{2}{*}{ Cultivar } & \multicolumn{6}{|c|}{1997} & \multirow[b]{2}{*}{ Dec. } & \multicolumn{11}{|c|}{1998} \\
\hline & Jun. & Jul. & Aug. & Sept. & Oct. & Nov. & & Jan. & Feb. & Mar. & Apr. & May & Jun. & Jul. & Aug. & Sept. & Oct. & Nov. \\
\hline \multicolumn{19}{|c|}{ High shoot density cultivars } \\
\hline Penn A1 & 8.42 & 7.49 & 6.63 & 4.87 & 4.80 & 2.90 & 6.09 & 8.84 & 7.64 & 7.94 & 5.85 & 10.96 & 10.73 & 5.41 & 1.09 & 0.37 & 0.98 & 5.09 \\
\hline Penn A2 & 7.77 & 5.64 & 8.28 & 5.04 & 8.19 & 4.02 & 4.94 & 8.35 & 6.04 & 6.37 & 5.35 & 9.38 & 10.21 & 6.47 & 1.18 & 0.54 & 0.79 & 3.95 \\
\hline Penn A4 & 8.60 & 7.33 & 7.91 & 5.24 & 4.53 & 3.62 & 4.85 & 8.12 & 7.92 & 8.29 & 6.30 & 12.57 & 9.38 & 7.50 & 1.12 & 0.52 & 1.14 & 6.98 \\
\hline Penn G1 & 6.85 & 5.41 & 7.27 & 5.49 & 3.49 & 3.05 & 6.60 & 7.76 & 7.39 & 5.89 & 5.63 & 8.21 & 10.08 & 6.20 & 1.18 & 0.46 & 0.74 & 4.91 \\
\hline Penn G2 & 7.55 & 5.94 & 8.47 & 5.58 & 4.05 & 3.23 & 7.85 & 8.08 & 6.96 & 9.38 & 6.28 & 8.88 & 10.10 & 6.55 & 0.97 & 0.32 & 0.92 & 4.27 \\
\hline Penn G6 & 6.75 & 6.80 & 8.95 & 4.14 & 3.73 & 3.05 & 5.71 & 8.45 & 7.21 & 7.64 & 6.53 & 8.85 & 10.18 & 7.57 & 0.54 & 0.52 & 0.87 & 4.76 \\
\hline \multicolumn{19}{|c|}{ Standard cultivars } \\
\hline Penncross & 8.24 & 4.78 & 8.58 & 6.16 & 4.52 & 3.79 & 4.78 & 8.92 & 5.97 & 8.52 & 6.30 & 7.99 & 9.98 & 7.77 & 1.59 & 1.22 & 1.35 & 6.07 \\
\hline Crenshaw & 8.17 & 7.37 & 7.76 & 4.75 & 3.87 & 4.08 & 5.97 & 9.92 & 6.10 & 8.06 & 8.47 & 9.53 & 9.49 & 7.07 & 1.41 & 0.19 & 1.09 & 6.00 \\
\hline Southshore & 8.09 & 4.16 & 8.38 & 5.15 & 3.61 & 3.43 & 6.54 & 7.81 & 7.63 & 8.42 & 6.21 & 8.36 & 9.19 & 4.88 & 1.65 & 0.29 & 0.75 & 4.85 \\
\hline DF-1 & 6.25 & 5.36 & 9.12 & 5.81 & 4.10 & 3.95 & 7.28 & 8.09 & 7.16 & 7.57 & 5.95 & 8.87 & 10.42 & 7.73 & 1.32 & 0.56 & 1.55 & 5.62 \\
\hline Procup & 6.74 & 5.90 & 7.20 & 5.12 & 4.63 & 2.80 & 6.36 & 7.93 & 7.43 & 9.97 & 4.05 & 9.30 & 10.44 & 5.18 & 1.86 & 0.52 & 0.72 & 5.50 \\
\hline Lopez & 7.39 & 5.77 & 8.11 & 5.62 & 4.01 & 4.05 & 5.12 & 10.72 & 6.83 & 7.34 & 5.74 & 10.05 & 11.17 & 7.13 & 1.22 & 0.72 & 1.08 & 5.46 \\
\hline SR 1020 & 7.70 & 7.53 & 9.16 & 5.63 & 4.09 & 4.10 & 5.36 & 8.80 & 6.70 & 7.55 & 6.79 & 9.83 & 11.17 & 6.93 & 1.27 & 0.43 & 1.42 & 6.26 \\
\hline Providence & 7.60 & 5.97 & 6.50 & 4.79 & 4.59 & 3.57 & 6.24 & 7.58 & 7.46 & 7.48 & 5.70 & 9.36 & 10.02 & 6.46 & 1.37 & 0.42 & 1.24 & 5.86 \\
\hline Penn/Cren & 6.55 & 5.81 & 6.70 & 4.29 & 5.41 & 4.12 & 5.13 & 8.99 & 7.08 & 8.77 & 5.75 & 8.91 & 9.49 & 7.43 & 1.30 & 0.46 & 1.30 & 6.50 \\
\hline Mean & 7.51 & 6.08 & 7.94 & 5.18 & 4.51 & 3.58 & 5.92 & 8.56 & 6.56 & 7.75 & 6.06 & 9.39 & 10.14 & 6.69 & 1.18 & 0.50 & 1.06 & 5.47 \\
\hline LSD & NS & NS & NS & NS & $1.85^{*}$ & NS & NS & NS & NS & $2.02^{*}$ & NS & NS & NS & NS & NS & NS & NS & NS \\
\hline \multicolumn{19}{|c|}{ Mean } \\
\hline $\begin{array}{l}\text { High shoot } \\
\text { density cvs. }\end{array}$ & 7.65 & 6.44 & 7.92 & 5.06 & 4.80 & 3.31 & 6.01 & 8.27 & 7.19 & 7.56 & 5.99 & 9.81 & 10.11 & 6.17 & 1.01 & 0.46 & 0.91 & 4.99 \\
\hline Standard cvs. & 7.54 & 5.86 & 8.01 & 5.38 & 4.18 & 3.72 & 5.96 & 8.72 & 6.91 & 8.11 & 6.15 & 9.16 & 10.23 & 6.64 & 1.46 & 0.54 & 1.12 & 5.70 \\
\hline Significance & NS & NS & NS & NS & NS & NS & NS & NS & NS & NS & NS & NS & NS & NS & $*$ & NS & NS & NS \\
\hline
\end{tabular}

Ns, *Nonsignificant and significant at $P \leq 0.05$, respectively. 
No differences in root dry weight were observed among the cultivars for the root samples collected from June 1997 through Nov. 1998. When a contrast was performed, however, root dry weight was significantly greater $(P \leq 0.05)$ in the six high shoot density than in the eight standard cultivars in Mar. and May 1998 (Fig. 1). This suggests that during the spring, the high shoot density cultivars had more roots. Root weight decreased for all the cultivars from June 1997 to July 1997 (Fig. 1). This probably reflected the gradual drop of mowing height from 11 to $3.1 \mathrm{~mm}$ during this time.

Percentage of TNC was significantly different $(P \leq 0.05)$ among the entries on only two of the 18 sampling dates (Oct. 1997 and Mar. 1998) (Table 2). No obvious trends for increased percentage of TNC in either the high shoot density or standard cultivars were apparent. Contrasts between the two groups indicated a difference between them in Aug. 1998 (Fig. 1), but not in Aug. 1997. The cultivars in 1998 may have been under increased environmental stress. During the months prior to the Aug. 1998 sampling, mean air temperature was $24^{\circ} \mathrm{C}$, while the comparable value during 1997 was $21^{\circ} \mathrm{C}$. Thus, during periods of hightemperature stress the high shoot density cul- tivars may have had lower carbohydrate reserves than did the standard cultivars. Further work is needed to evaluate the performance of high shoot density cultivars under environmental stresses.

The high shoot density of creeping bentgrass cultivars, 'Penn A1', 'Penn A2', 'Penn A4', 'Penn G1', 'Penn G2', and 'Penn G6', had greater shoot densities than did the standard cultivars, but no consistent differences in root weight or TNC were apparent.

\section{Literature Cited}

Beard, J.B. 1973. Turfgrass science and culture. Prentice Hall, Englewood Cliffs, N.J.

Bonos, S.A. and J.A. Murphy. 1999. Growth responses and performance of Kentucky bluegrass under summer stress. Crop Sci. 39:770774.

Croce, P., M. Mocioni, and J.B. Beard. 1998. Agrostis cultivar characterization for closely mowed putting greens in Mediterranean climate, p. 668677. In: A. Cochran and M. Farrally (eds.). Science and Golf III. E\&FN Spon, London.

Huang, B., X. Li, and J.D. Fry. 1998. Effects of high temperature and poor aeration on root growth and viability of creeping bentgrass. Crop Sci. 38:1618-1622.

Hull, R. 1992. Energy relations and carbohydrate partitioning in turfgrass, p. 175-205. In: D.V.
Waddington, R.N. Carrow, and R.C. Sherman (eds.). Turfgrass. Amer. Soc. of Agron., Madison, Wis.

Sheffer, K.M., T.L. Watschke, and J.M. Duich. 1979. Carbohydrate sampling in Kentucky bluegrass turf. Agron. J. 71:301-304.

Skogley, C.R. and C.D. Sawyer. 1992. Field research, p. 589-614. In: D.V. Waddington, R.N. Carrow, and R.C. Sherman. (eds.). Turfgrass. Amer. Soc. of Agron., Madison, Wis.

Smith, D. 1968. Classification of several native North American grasses as starch or fructosan accumulators in relation to taxonomy. J. Brit. Grassland. Soc. 23:306-309.

Smith, D. 1981. Removing and analyzing total nonstructural carbohydrate from plant tissue. Wisconsin Agr. Expt. Sta. Res. Rpt. 2107.

Steele, R.G.D. and J.H. Torrie. 1980. Principles and procedures of statistics, a biometrical approach. McGraw-Hill, New York.

Watschke, T.L., R.L. Schmidt, and R.E. Blaser. 1970. Responses of some Kentucky bluegrasses to high temperature and nitrogen fertility. Crop Sci. 10:372-376.

Watschke, T.L., R.L. Schmidt, E.W. Carson, and R.E. Blaser. 1972. Some metabolic phenomena of Kentucky bluegrass under high temperature. Crop Sci. 12:87-90.

Watschke, T.L., R.L. Schmidt, E.W. Carson, and R.E. Blaser. 1973. Temperature influence on the physiology of selected cool season turfgrasses and bermudagrass. Crop Sci. 13:591-594. 